\title{
Resource Investment Model in Specifics of Developing Countries
}

\author{
Svetlana V. Orekhova \\ Chair of Corporate Economics \\ Ural State University of Economics \\ Ekaterinburg, Russian Federation \\ bentarask@list.ru
}

\author{
Evgeny A. Kuzmin \\ Chair of Corporate Economics \\ Ural State University of Economics \\ Ekaterinburg, Russian Federation \\ kuzminea@gmail.com
}

\begin{abstract}
The research was aimed at a search for characteristic criteria, using which it is possible to choose resource strategies specific for companies in the developing countries in the context of Russia. At the same time, differences between institutional environments of the developing and developed countries lead to ambiguous conclusions. The critical review of methodological approaches to the research has made it possible to obtain the reasonable evidence for the conclusion that managerial decision-making of the model depends on resource properties, as well as dynamic and structural parameters of the institutional environment (factors). The results, shown in the paper, say that it is necessary to revise the imperative paradigm about significance of the minimization criterion for cumulative costs and the expense ratio. Contrary to the reasonable focus on the accepted model of investment in non-specific assets, businesses in Russia apply the intermediate hybrid model with rigid boundaries and primarily institutional coordination mechanisms.
\end{abstract}

Keywords-resource strategy; institutional environment; transaction cost; developing countries.

\section{INTRODUCTION}

The global trend towards structural changes will depend more on a more intensive relocation of heavy industries from the centre to the periphery due to increasing differences in labour costs and environmental concerns [1]. The counter flow will express itself in an ongoing "brain drain" to the areas where businesses are more focused on a usage of so-called soft technologies. The specifics of such technologies is that, first, they require intellectual assets and rest on the human capital. Thus, the countries, able to create conditions for human capital keeping and development will become a centre in the new global economic system [2,3]. At the same time, the conditions of doing business in the developing markets are very different from those in the developed markets. This fact explains the differences in the nature of competitive advantages of companies and, consequently, differences in their management practices.

Like other developing countries, Russia has faced the phenomenon of so-called "black swans" ([4]), i.e. a number of events, described with unpredictability and powerful effects for the national economy. Under these new conditions, it is important to understand which resources the Russian economy has and which investment landmarks are available.

Two mentioned elements are a direct focus of this research. To achieve the set goal, it is necessary to: 1) make a comparison study of a meaning for the category of 'resources' against today's strategic management theories; 2) distinguish possible investment models of resource mobilization with described advantages and disadvantages; 3) identify the factors that explain a choice of a model for resource mobilization applied by Russian companies.

\section{LITERATURE REVIEW}

\section{A. Typology of resources}

A corporate strategic choice is a result of a dynamic interaction of the company with the institutional environment [5-7] and the best "benefit-cost" ratio is a focus of this result. Here it is worth mentioning the Alchian's statement, “...the subject matter in economic theory includes property rights for scarce resources" [8, p.2]. Therefore, the company's focus is finding out how to achieve the best possible economic results with the least investments in resources. In [9], there are explanations that the organizational effectiveness depends on two components, i.e., institutions and resources.

When a company develops its resource strategy, it first reviews a need and a way of investment into assets. The strategic choice of an investment rest upon the following options: a resource purchase to get the resource into private property, the development of available resources or creation of new ones in-house. There are also borrowings or other resource involvement ways in the market [10].

Generally, resources refer to everything that supports the company's functioning. According to Hofer and Shendel [11, p.145], the company's competitive advantages depend on six types of resources, including financial, tangible, human, technological, organizational, and reputational. Grant [12, p.119] included intangible resources into this typology. Later [13, p.147], he identified three groups of resources: tangible, intangible, and human. Apart from the conventional list, Hunt [14] identified the seventh resource type, legal resources.

The review of available resource classifications has shown that the typology of the resource portfolio, introduced by Ruus et al. $[15$, p.24-25] is the most comprehensive. The development of this classification made it later possible to identify five groups of assets: human, relationship, 
organizational, tangible, and financial. Each groups has a different ratio of tangible and nontangible components that influence the resource specifics.

\section{B. Some approaches to definition of resource properties}

Economic theories that link the formation of long-term competitive advantages of a company to resource management assume their different content and selection criteria. The key idea in the today's resource-based view (RBV) is that "competitive advantage lies 'upstream' of product markets and rests on the company's idiosyncratic and difficult-to-imitate resources" [16, p.46]. Barney articulated the first analytical evaluation scheme for the resource within the resource-based view. He offered four variable parameters [17]: value (V), rarity (R), imitability (I), and indispensability of the organizational model. Barney's research provided an impetus for a use of this analytical framework in other papers (like [18]), explaining resource properties.

The difficulty of resource imitation is a key factor in cases when it is necessary to choose a way of investment and in theories of neo institutional economy. However, its importance depends on an increase in transaction cost instead of its value. The resources are peculiar assets and it is impossible to use them in an alternative way without a significant loss in their capacity [19, p.167]. It is the challenge of resource transfer that makes their heterogeneity long-term and their competitive advantages strong.

According to the relationship view (RV), for which Dyer and Singh [20] were founders, the ability of a company to accumulate and gather together market resources, pushing the market borders, is a key factor for its long-term success. A unit of analysis here is an inter-organisational network, where there are assumptions within its framework to use shared assets of several companies, located (as a rule, but not always) at various stages of the value chain.

The main difference between RBV and RV is a choice of the source for the sustained competitive advantage: due to isolating mechanisms (the principle saying that "nobody can imitate this') or an ability that the company has when it gathers borrowed resources. The quality of asset 'causative ambiguity' for network's participants, unlike the supporters of the resource-based view, is a factor that leads to a lower investment attractiveness of the resource. The comparative terminological analysis of the category of "resources" in terms of the resource-based view and relationship concept makes it possible to identify a number of key distinctions (tab. $1)$.

TABLE 1. COMPARATIVE ANALYSIS OF THE CATEGORY OF “RESOURCES” IN TERMS OF RESOURCE BASED AND RELATIONSHIP VIEWS

\begin{tabular}{|c|c|c|}
\hline Subject of comparison & Resource-based view (RBV) & Relationship view (RV) \\
\hline Resource definition & $\begin{array}{l}\text { Based on production factors, there are corporate } \\
\text { specific assets, which are difficult or impossible to be } \\
\text { imitated and which make it possible for a company to } \\
\text { implement strategies, contributing to its economic and } \\
\text { management effectiveness }\end{array}$ & $\begin{array}{l}\text { Ability of a company to accumulate and gather market } \\
\text { resources, pushing borders of the market itself } \\
\text { (increasing a circle of consumers and other partners) }\end{array}$ \\
\hline $\begin{array}{l}\text { Resource transformation } \\
\text { area }\end{array}$ & Company & Network (hybrid) \\
\hline Resource useful life & Medium-term and long-term & Short-term and long-term \\
\hline $\begin{array}{l}\text { Type of rent from resource } \\
\text { use }\end{array}$ & $\begin{array}{l}\text { Quasi-rent is a way to get economic benefits in the } \\
\text { manner when companies receive a disproportionate } \\
\text { share of other economic rents compared to their } \\
\text { competitors: Ricardian (income from possession of } \\
\text { finite valuables), monopoly (income from market } \\
\text { power) and business (income from risks and } \\
\text { innovations) }\end{array}$ & $\begin{array}{l}\text { The relationship rent is an excess profit, mutually made } \\
\text { as a result of exchange relationship, when it is } \\
\text { impossible for one company to make such profit } \\
\text { separately and which it is only possible to achieve with } \\
\text { mutual idiosyncratic efforts of focused partners within } \\
\text { alliances }\end{array}$ \\
\hline Property level for resource & $\begin{array}{ll}- & \text { possession } \\
- & \text { disposal } \\
- & \text { use (all the right in full belong to the company) }\end{array}$ & $\begin{array}{ll}- & \text { disposal (it is possible to limit it) } \\
- & \text { use (it is possible to limit it) }\end{array}$ \\
\hline $\begin{array}{l}\text { Achievement of a } \\
\text { competitive advantage }\end{array}$ & Due to resource heterogeneity & $\begin{array}{l}\text { Due to a spread of network participants' resources } \\
\text { across the entire network }\end{array}$ \\
\hline $\begin{array}{l}\text { Important features of a } \\
\text { resource }\end{array}$ & $\begin{array}{ll} & \text { difficulty to imitate and reproduce a resource } \\
- & \text { durability (ability of a resource not to lose its value } \\
\text { over time) }\end{array}$ & $\begin{array}{ll}- & \text { complementarity (resource compatibility with } \\
\text { others) } & \\
\text { - flexibility (resource use for different strategies } \\
\text { without a radical change of its importance and } \\
\text { costs of its use) }\end{array}$ \\
\hline Market behaviour & $\begin{array}{l}\text { Based on competition (owing to the generated features } \\
\text { of resource uniqueness and difficulty to be imitated) }\end{array}$ & Based on cooperation (owing to shared resource use) \\
\hline
\end{tabular}

The synthesis of resource-based view and relationship view makes it possible to treat resources as specific in relation to market assets controlled by a company completely or partially. Respectively, with the control over resources, a company can achieve competitive advantages without their purchase. Redistribution of this control occurs when companies keep their formally independent existence [21, p.32] and depends on a level of negotiating power that parties have, costs for control, a volume of specific investment in relationships with partners and the contract progress. 


\section{MODEL}

Referring to the resource-based and the relationship views, it is possible to distinguish two major resource investment models: the model, focused on an acquisition of assets; and the model, focused on a temporary mobilization of resources available in the network or market. Companies choose the strategy by analysing incentives and comparing costs and benefits connected with property rights in transition. It is possible to explain them within the theory of institutional change. The choice between investment resource models is worth considering by comparing costs and benefits from exclusive rights for resources (excluding other individuals from an access to resources), on the one hand, and internal network costs for shared property management incurred by a group of individuals, on the other hand.

There is a formalization of the resource strategy choice in the model offered by [22]. In this exact case, the synthesis of two factors (compared resource properties and institutional market parameters) leads to a different ratio between transformation $(\mathrm{Ctf})$ and transaction costs $(\mathrm{Cts})$ as investments in resources. In the consolidation of standards (in this case, it is the resource model), transaction and transformation costs change in opposite directions, the decrease in the first ones is accompanied by the increase in the second ones [22]. Hereinafter transformation costs are considered costs of property rights in transition, i.e. transformation of standards.

The general framework of the resource strategy choice is as follows. Let us introduce initial conditions. Suppose that there is $n$ number of companies in the market. Each of them can use two ways of resource exchange, i.e. with and without transition of property rights. As the best possible institutional alternative is the one with the minimum of transformation and transaction costs, the choice of the resource strategy will depend on the model of the following type:

$$
\mathrm{Xj} \times \mathrm{Cts}\left(\mathrm{Xj}_{\mathrm{j}}+\sum_{\mathrm{i}^{\prime} \mathrm{j}} \mathrm{Xi}\right)+\left(1-\mathrm{Xj}_{\mathbf{j}}\right) \times \mathrm{Ctf}\left(\mathrm{Xj}_{\mathrm{j}}+\sum_{\mathrm{i}^{1} \mathrm{j}} \mathrm{Xi}\right) \rightarrow \min
$$

where $\mathrm{Ctf}$ is transformation costs; $\mathrm{Cts}$ is transaction costs; $\mathrm{Xj}$ is a share of transactions per $\mathrm{j}$-th agent in case of resource attracted in the network; $(1-\mathrm{Xj})$ is a $\mathrm{j}$-agent share in case of resource acquisition; $\mathrm{Xi}$ is a total volume of resource attracted in the network by all the agents; Cts $\times \sum_{\mathrm{n}}^{1} \mathrm{Xi}$ is costs for exchange of the unit of resources attracted in the network; $\mathrm{Ctf} \times \sum_{\mathrm{n}}^{1} \mathrm{Xi}$ is costs per resource unit in case of a property rights transfer.

For sure, the choice of a model will depend on a size of a company, its life cycle and industry. However, a breakdown of the factors that cause the specifics of the resource usage, shows a global trend when the larger companies' enhancement increment of abilities causes co-optation of their resources in a business chain. SO, in the network the use of resources can have soft and rigid barriers.

The growth of benefits from used hybrid (network) forms of business organization is primarily due to globalization that significantly simplifies flows of capital between territories and markets. Lower barriers for an entrance to regional markets have resulted in more intense competition that requires a large number of resources from a company to keep its market share. As a result, in today's markets, there is a higher concentration and number of industrial and inter-industrial alliances. The second reason for the active networking is a pace of technological changes and total informatization of the society. It is impossible to get long-term competitive advantages with a unique resource only as it rapidly gets old and losses its value. In case when the technology is a major competitive advantage of a company, the company seeks to share the costs of proactive modernization with its partners. Bearing in mind this kind of partners' behaviour, companies tend to underinvest into specific assets and this causes a very negative impact on networking and the general effectiveness of the network. It is impossible to compare these costs as they have different frequency [22]. Generally, as long as participants' costs for a support to network relationships are lower (Cts) than costs for resource acquisition (Ctf), hybrid (network) forms of business organization will remain much more profitable.

\section{RESULTS}

According to numerous statistical and empirical data, in Russia, the model focused on resource borrowing from the network is used everywhere [23], [24, p.517-538]. Moreover, the extreme option of this model called the self-sufficiency strategy is more and more popular among businesses. The choice of this resource model and the attractiveness of investments in various resources depend on the developmental specifics in the Russian institutional environment [25]. The model rests on extractive institutions instead of inclusive ones (terminology is from [26]). It is possible to divide institutional factors into dynamic and structural (fig. 1).

To summarize, dynamic factors define the planning horizon in investment decision making, while structural factors define the interaction quality and the element coherence in the institutional environment.

\section{A. Dynamic institutional factors}

It is well known that owned resources only provide the better corporate performance in a stable environment (e.g., Miller and Shamsi [27, p.271-273]). According to [28, p.63], a lifecycle of small and medium-sized enterprises in Russia is 14 years on the average, only 5.5 years of them are at the stages of development and maturity. This fact causes short period of business tasks, while the competition is based on asset liquidity and strategic flexibility. Under these conditions, a possession of peculiar resources might become a burden.

Another feature in the Russian institutional environment is the misbalance between institutional reforms, which devaluate positive effects of changes. For example, according to global rating Doing Business2016 (http://russian.doingbusiness.org), Russia is the 5th by the parameter of contract execution, and only the 119th by the parameter called 'procurement of construction permit.' The asynchrony of institutional changes is also due to the fact that informal institutions are transformed for a longer time than 
formal ones.

Under turbulence conditions, companies can only develop short-term strategies (actually the tactic instead of the strategy, as the term 'strategy' originally assumes long-term planning), their main objective is a survival instead of development. Due to superiority of short-term tasks, businesses seek to reduce their tax base, i.e. to minimize their asset size, which they have to recognize on their balance sheet.

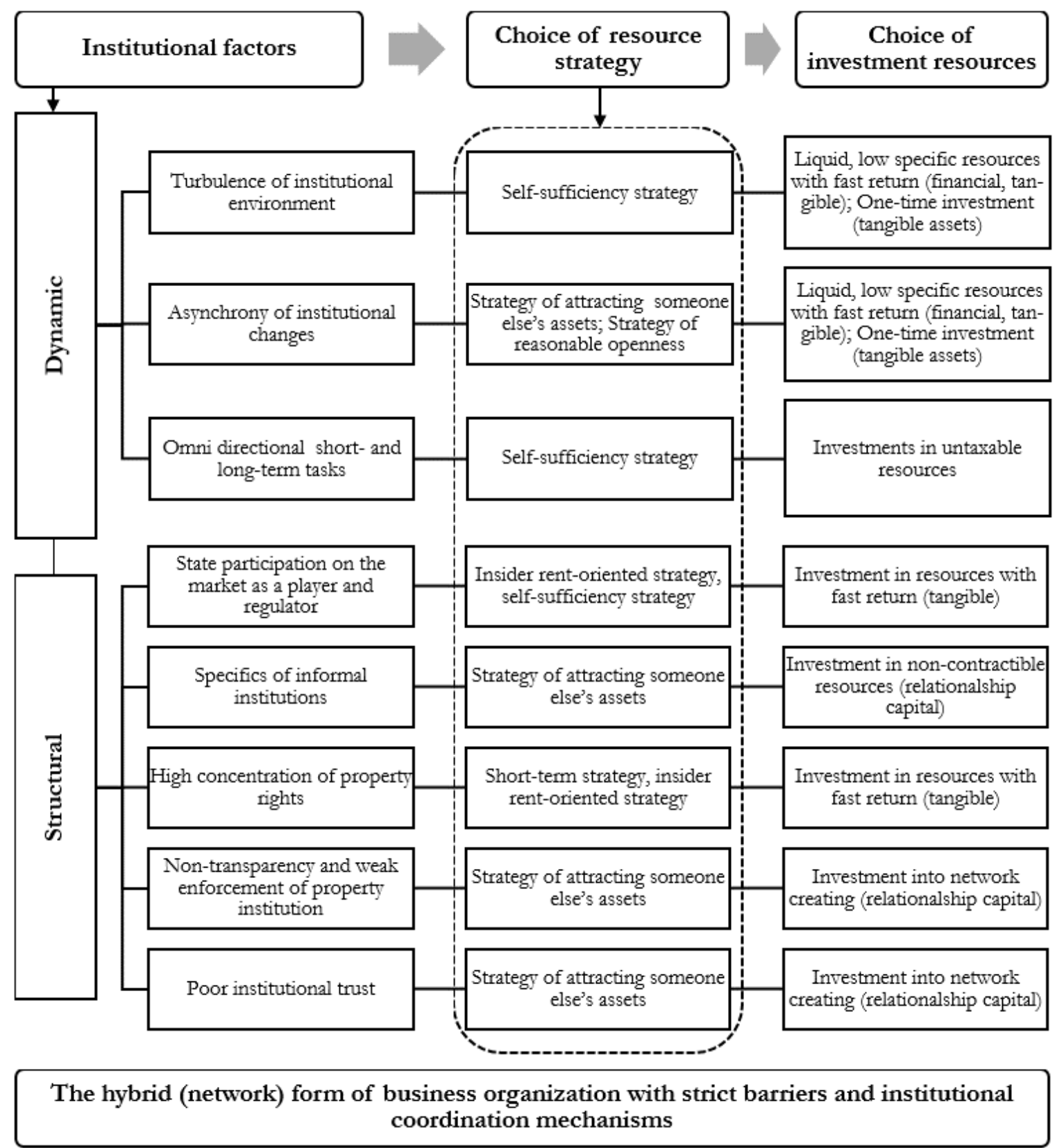

Fig. 1. Institutional factors that influence a choice of a resource investment model in Russia

\section{B. Structural institutional factors}

Among the structural misbalances in the Russian institutional environment, professionals mention the multilevel nature, dualism of formal and informal rules, inconsistency between existing rules and enforcement mechanisms, component incompleteness and fragmentary and also dependence of the institutional environment on the Russian political market [29]. As a result, market participants tend to transfer their resources into more protected forms (usually money) and take over the assets owned by 'others.'

The primary resource allocation, caused by the privatization specifics in Russia, led to a minor role of small and medium-sized enterprises in the Russian economy and their hyper concentration [30], [31]. As a result, the integration of companies and asset consolidation are the main trend in the most of Russian markets including those that are historically competitive. 
The level of trust (bonding force) towards a partner is the main criterion for networking. The bonding force defines a distance to a resource, while the trust level regulates a power of this bonding force. Though, according to [23, p.7] "in transitional economies with weak institutions, the strong influence of informal relationships on the parameters of interfirm cooperation has not been found," the specifics of these relationships in Russia generates peculiar forms of resource management. Because of such high business concentration, relationships between market participants are mostly personalized, based on the system of relationship contracts. At the same time, due to the low level of institutional trust, there are formal obligations behind them.

Apart from 'competition' between efficient and nonefficient entrepreneurs, the latter ones also have to compete with the government as an owner. Another feature of the institutional environment is a specific type of the Russian economic setup described as state capitalism. It follows from [32], [33] that in BRIC markets, the government plays a more active role than it is common in the long-established market economy. Despite the ongoing privatization and a formal decrease in a number of government-owned enterprises, according to [34], in the ownership structure of 10 largest Russian companies, the government's share is about $80 \%$, while a share of state-owned enterprises in capitalization of the Russian stock market is over $60 \%$.

\section{DISCUSSION}

The influence review of institutional factors under research makes it possible to state that Russian businesses actively use hybrid forms of management and invest into networking (relationship capital). In this case, idiosyncratic resources generated by a company (primarily, human and organizational capital) are not only inexhaustible source of income, but also a basis for an increment of other groups of assets [2], [3]. In other words, the model focused on own asset increments is more prospective for Russian businesses.

Ideally, exposed to uncertainty, companies can only choose two out of three available forms of management, the market (in case of a nonspecific transaction) or the company (in case of an exotic transaction) [35]. The hybrid form of management (synthesis of market and institutional coordination mechanisms), where a radical transformation appears, is not used due to many risks for both sides. This means that in terms of a volatile institutional environment companies do not have to invest into peculiar assets and participate in complicated networking relationships due to increasing transaction costs.

It is possible to explain this seeming disparity between theoretical background and the Russian reality with a number of reasons. There is the image of the network as a system of relationships with suppliers, employees, and consumers, where costs are important, but not as important as social and environmental effects [36]. The image is false in the Russian reality. Networks mainly appear due to tax and antimonopoly legislation instead of the real resource sharing between companies. The hybrid in Russia is not a result of used asset specificity. It is rather of particular goals that owners have as for their use.
As an example, it would be reasonable to consider the Russian outsource pattern. The classical outsourcing is a common example of the hybrid with soft 'borders,' when a company delegates some of its business processes to another one. A user company has quite a low degree of control over the resources owned by an outsourcer. Nevertheless, in Russia, the outsourcing model is often an artificial mechanism of two formally independent companies. City-forming and other large industrial enterprises exclude from their structure repairs, energy, and transport production facilities encouraging them to make profit independently. However, the geo-distance from end markets, narrow vocational profile of the outsourcing company and customer's control over costs lead to the situation when with the formal legal independence, the outsourcer does not have its business independence. This mechanism does not allow using the advantages of 'pure' strategies in full, resource borrowing from the network or purchasing them as private property. Hence, it leads to increasing cumulative transaction and transformation costs.

In [22], the so-called effect of hysteresis is mentioned, when apart from 'pure' strategies sustainable (equilibrium) mixed strategies appear. The core of this effect is that upon a strong 'disturbance' in the institutional environment, the standard might get into an institutional trap and stay there even when there is no more such 'disturbance.'

Going on with the model-based discussion (1), it makes sense to introduce the following:

$\mathrm{Yj}$ is a share of resource borrowing in the network upon a refusal from purchasing to get it into private property,

$\mathrm{Ctf}^{0}$ are costs for purchasing of the resource as the private property (transformation costs),

$\mathrm{Ctf}^{1}$ are costs of a transition from networking to purchasing to get resources into private property.

Then, using the models (2) and (3), it is possible to show the choice of a resource strategy made by a market participant:

$$
\operatorname{Ctf}\left(X_{j}, Y_{j}\right)=\left\{\begin{array}{l}
\left(1-Y_{j}\right) \times C_{t f}^{0}+\left(Y_{j}-X_{j}\right) \times C^{1} f^{1}, X j<Y_{j} \\
(1-X j) \times C t f^{\circ}, X^{3} Y_{j}
\end{array}\right.
$$

This implies:

$$
\mathrm{Xj} \times \mathrm{Cts}\left(\mathrm{Xj}_{\mathbf{j}}+\sum_{\mathrm{i}^{\prime} \mathrm{j}} \mathrm{Xi}\right)+\mathrm{Ctf}(\mathrm{Xj}, \mathrm{Yj}) \rightarrow \min .
$$

Thus, the hybrid model of resource management in the Russian economy is actually in-house (based on institutional coordination mechanisms). At the same time, the network trust is a key to understand the reasons behind the appeal of hybrids in Russia. Unlike classical theories, based on Williamson's model, networks in the Russian institutional environment can serve as a particular way that helps to reduce an uncertainty level. The key element for the network trust is a close state of contacts [37]. Hence, hybrids with rigid borders are widely preferred. At the same time, the level of resource deficit in the market and the level of resourcing in the network play the main role here. The higher this resourcing and resource deficit are outside the network, the more incentives business entities have not to depart from contract obligations taken by 
participants in hybrids.

\section{CONCLUSION}

Resource ownership relationships between market participants are controlled with market (price) and institutional coordination mechanisms. Each of the available investment models (purchase to get into private property or engage in networks (in the market) has its pros and cons. The impact of institution-specific factors has led to the use of the intermediate model in Russia, a hybrid form of business organization with rigid borders and mainly institutional coordination mechanisms. Existing institutional practices dictate companies to use short-term resource investment strategies as the most profitable. The minimization of investments as such is a common strategic vector in resource management. Russian companies seek to network to attract resources of other market participants. To implement this resource strategy, investments into the relationship capital are anyway necessary.

It seems that in order to choose the investment forms for the corporate resource portfolio, the balanced application of two strategies is the best strategic decision. At the same time, the focus is usually made on the resource, which is a key factor for the business success. In order to make this resource unique, it has to be purchased in private property, while it is possible to involve other assets for temporary use. An application of the existing model of resource management is the main reason of difficulties that Russian enterprises face when they want 'reloading' to get on the innovative path of development. However, the review of this strategy will be only possible upon essential institutional reforms and interaction rules introduced for all the market participants.

\section{References}

[1] Ya. Kuzminov and A.Yakovlev, "Modernization of the economy: global trends, the basic constraints and policy options". Working Paper WP5/2002/01. Moscow: Higher School of Economics, 2002.

[2] R. A. Brymer, J. C. Molloy and B. A. Gilbert,. Human "Capital Pipelines," Journal of Management, 40(2), pp. 483-508, 2014.

[3] B. A. Campbell, "Rethinking sustained competitive advantage from human capital," Academy of Management review, 37(3), pp. 376395, 2012. http://dx.doi.org/10.5465/amr.2010.0276

[4] N. N. Taleb, "The Black Swan: The Impact of the Highly Improbable". N. Y.: Random House, 2007.

[5] M. Peng, "Institutional transitions and strategic choices," Academy of Management Review, 28(1), pp. 275-296, 2003. http://dx.doi.org/10.5465/AMR.2003.9416341

[6] Y. Luo, J. Sun and S. L. Wang, "Comparative strategic management: An emergent field in international management," Journal of International Management, 17(3), pp. 190-200, 2011. http://dx.doi.org/10.1016/j.intman.2011.05.002

[7] N. Popov and O. Tretyak, "Economic factors lower customer-focus companies in the BRIC countries," Russian Management Journal, 12(31), pp. 109-138, 2014.

[8] A. A. Alchian, "Pricing and Society". Occasional Papers, No 17. London: Institute of Economic, 1967.

[9] D. B. Zoogan, M. W. Peng and H. Woldu, "Institutions, resources and organizational effectiveness in Africa," Academy of Management Perspectives, 29(1), pp. 7-31, 2015. http://dx.doi.org/10.5465/amp.2012.0033

[10] S. Orekhova and F. Legotin, "Creating a resource strategy of firm in the context of RBV-analysis," Journal of the Ural State University of Economics, 4, pp.15-26, 2015.

[11] C. W. Hofer and D. Schendel, "Strategy Formulation: Analytical
Concepts". St. Paul, MN: West Publishing Co., 1978.

[12] R. M. Grant, "The Resource-Based Theory of Competitive Advantage: Implications for Strategy Formulation," California Management Review, 33(3), pp.114-135, 1991. http://dx.doi.org/10.2307/41166664

[13] R. M. Grant, "Modern strategic analysis" [Translation]. St. Petersburg: Piter, 2001.

[14] S. D. Hunt, "A General Theory of Competition: Resources, Competences, Productivity, Economic Growth". Thousand Oaks, California: Sage Publications, 2000.

[15] J. Ruus, S. Pike and L. Fernstrem, "Intellectual capital: the practice management". St. Petersburg: High School of Management, University Press, 2008

[16] D. J. Teece, "Towards an economic theory of the multiproduct firm," Journal of Economic Behavior and Organization, 3, pp. 39-63, 1982. http://dx.doi.org/10.1016/0167-2681(82)90003-8

[17] J. B. Burney, "Firm recourses and sustained competitive advantage," Journal of Management, 17(1), pp. 99-120, 1991.

[18] R. Amit, and P. J. H. Schoemaker, "Strategic assets and organizational rent," Strategic Management Journal, 14 (1), pp. 3346, 1993. http://dx.doi.org/10.1002/smj.4250140105

[19] O. Williamson, "Economic Institutions of Capitalism: Firms, Markets, Relational contracting" [Translation]. St. Petersburg: Lenizdat; CEV Press, 1996.

[20] J. H. Dyer and H. Singh, "The relational view: Cooperative strategy, sources of interorganizational competitive advantage," Academy of Management Review, 23(4), pp. 660-679, 1998. http://dx.doi.org/10.2307/259056

[21] N. Dzagurova, "Corporate investment and the reasons for underinvestment in specific assets," Russian Journal of Management, 10(4), pp. 31-48, 2012.

[22] V. M. Polterovich, "Institutional traps and economic reforms," Economics and Mathematical Methods, 35(2), pp. 1-37, 1999.

[23] S. Avdasheva and N. Goreyko, "Mechanisms of transaction management in the Russian manufacturing industry," Russian Journal of Management, 9(31), pp. 3-28, 2011.

[24] E. Popov, "Institutes". Ekaterinburg, Russian: Institute of Economics Ural Branch of RAS, 2015.

[25] E. A. Kuzmin and O. M. Barbakov, "Institutional Efficiency and Processes of Institutional Changes (as Seen by the Russian Academic Tradition)," Asian Social Science, 11(6), pp. 163-170, 2015. http://dx.doi.org/10.5539/ass.v11n6p163

[26] D. Acemoglu and J. A. Robinson, "Why Nations Fail: the origins of power, prosperity, and pov-erty". N.Y.: Crown Business Publishers, 2012.

[27] K. Fleischer and B. Bensoussan, "Strategic and Competitive Analysis. Methods and tools for competitive analysis, business". Moscow: Binom, 2012.

[28] A. Shamray (Ed.), "Life cycle of a small business". Moscow: Fund Liberal Missio, 2010.

[29] A. Shastitko, "Institutional environment management in Russia: the main characteristics". In T. I. Zaslavskaya (Ed.) Where is Russia? .The crisis of institutional systems: Age, decade, year (pp. 201-205). Moscow: Logos, 1999.

[30] T. Dolgopyatova, "Evolution of the structure and dynamics of the concentration of ownership". In B. V. Kuznetsov (Ed.) Essays on modernization of Russian industry: the behavior of firms (pp. 143166). Moscow: Publishing House of HSE, 2014.

[31] G. Zhoga, "How to cheat conjuncture," Journal Expert-Ural, Ekaterinburg, (September 28, 2015). Retrieved from http://goo.gl/rxcSIQ

[32] X. Li and X. L. Wang, "A Model of Chinas State Capitalism". Working Paper. Hong Kong: Hong Kong University of Science and Technology, 2012. Retrieved from http://ssrn.com/abstract=2061521

[33] A. Musacchio and S. G. Lazzarini, "Reinventing State Capitalism: Leviathan in Business, Brazil and Beyond". Cambridge, MA: Harvard University $\quad$ Press, 2014. http://dx.doi.org/10.4159/harvard.9780674419582

[34] A. L. Kudrin and E. T. Gurvich, "Government Stimulus or Economic Incentives?," Journal of the New Economic Association, 2(26), 2015, pp. $179-186$.

[35] O. Williamson, "Markets and Hierarchies: Analysis and Antitrust 
Implications". N. Y.: Free Press, 1975.

[36] N. Haigh and A. J. Hoffman, "Hybrid organizations: The next chapter of sustainable business," Organizational Dynamics, 41, pp. 126-134, 2012. http://dx.doi.org/10.1016/j.orgdyn.2012.01.006
[37] M. S. Granovetter, "The Strength of Weak Ties," American Journal of Sociology, 78(6), pp. 1360-1380, 1973. http://dx.doi.org/10.1086/225469 